\title{
Valuing Investment Decisions: Flotation Costs And Capital Budgeting
}

Neeraj J. Gupta, Elon University, USA

Wonhi Synn, Elon University, USA

\begin{abstract}
We highlight a measurement problem inherent in the prevalent approach to factoring flotation costs in capital budgeting decision-making. This arises because the traditional method calculates a higher cost of capital, while keeping the initial cash-flow unchanged. We demonstrate an alternate approach that corrects for this problem by assigning a higher initial investment due to flotation costs, while keeping the cost of capital unchanged.
\end{abstract}

Keywords: Flotation costs, capital budgeting, investment decisions, valuing, project analysis

\section{INTRODUCTION}

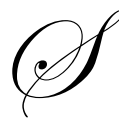

hareholder wealth maximization is the primary goal of a corporation, and the foremost mandate of its financial managers. Capital allocation and budgeting decisions play a significant role in this value creation. The contemporary corporate finance education literature extensively discusses various criteria to evaluate capital budgeting decisions. Graham and Harvey (2001) find that most firms use Net Present Value (NPV), Internal Rate of Return (IRR), Payback, or the Profitability Index.

Academics argue that NPV is the most theoretically rigorous, a view supported by most financial managers - 75 percent of firms surveyed by Graham and Harvey (2001) always or almost always use NPV as their investment criterion; the proportion of large firms using NPV is even higher.

For a project under consideration, NPV is calculated as the present value of expected cash-flows discounted at the firm's weighted average cost of capital:

$\mathrm{NPV}_{0}=-\mathrm{C}_{0}+\sum_{\mathrm{i}=1}^{\mathrm{n}} \frac{\mathrm{C}_{\mathrm{i}}}{(1+\mathrm{WACC})^{\mathrm{i}}}$

where,

$\mathrm{NPV}_{0}$ is the net present value of the project today (time 0 ),

$\mathrm{C}_{0}$ is the cash-flow in project today (the project investment),

$\mathrm{C}_{\mathrm{i}}$ is the cash-flow from project at future time $i$, and

$\mathrm{n}$ is the period in which last cash-flow occurs.

The firm's weighted average cost of capital (WACC) is the market-value weighted average of the various components of the firm's capital:

$\mathbf{W A C C}=\mathbf{w}_{\mathrm{d}} \mathbf{r}_{\mathrm{d}}+\mathbf{w}_{\mathrm{ps}} \mathbf{r}_{\mathrm{ps}}+\mathbf{w}_{\mathrm{cs}} \mathbf{r}_{\mathrm{cs}}$

$\mathbf{r}_{d}=\mathbf{r}_{d, \text { pretax }}(\mathbf{1}-\mathbf{T})$

where, 
$\mathrm{w}_{\mathrm{d}}, \mathrm{w}_{\mathrm{ps}}, \mathrm{w}_{\mathrm{cs}}$ are the proportion of firm's capital invested in debt, preferred stock, and common stock, respectively, $\mathrm{r}_{\mathrm{d}}, \mathrm{r}_{\mathrm{ps}}, \mathrm{r}_{\mathrm{cs}}$ are the rates of return on firm's debt (after-tax), preferred stock, and common stock, respectively, and $\mathrm{T}$ is the marginal federal-plus-state tax rate for the firm.

The literature, however, inadequately addresses how to handle flotation costs in the context of a firm using new capital to finance projects. The traditional treatment in textbooks has been to adjust the discount rate to include flotation costs. This approach is advocated by popular finance textbooks used for undergraduate and graduate courses in colleges and universities globally. Slightly different variations of the traditional approach can be found in textbooks such as Brigham and Houston (2007), Brealey, Myers and Marcus (2007), Brigham and Ehrhardt (2005), Ross, Westerfield, and Jaffe (2002), Ross, Westerfield, and Jordan (2002), Brealey and Myers (2000).

In the following section, we discuss the prevalent approach in depth, and demonstrate that it incorrectly assigns a higher cost of capital and lower initial investment, thus biasing the measurement of NPV. This implies that managers evaluating whether to invest in projects may be incorrectly undervaluing (overvaluing) NPV, and rejecting (accepting) projects that is, in fact, viable (unviable). We also detail an approach, used in only one textbook, which overcomes these measurement errors, and provides managers more accurate and rigorous decisionmaking criteria.

\section{INCORPORATING FLOTATION COSTS USING THE TRADITIONAL APPROACH}

The traditional literature estimates the costs of the new capital components in many different ways. For example, Brigham and Houston (2007) solve for them as:

$$
\begin{aligned}
& \mathbf{P V}_{d}\left(1-F_{d}\right)=\sum_{j=1}^{t} \frac{P_{d}(1-T)}{\left(1+r_{d}^{f}\right)^{j}}+\frac{F_{d}}{\left(1+r_{d}^{f}\right)^{t}} \\
& r_{p s}^{f}=\frac{r_{p s}}{1-F_{p s}} \\
& \mathbf{r}_{c s}^{f}=\frac{r_{c s}-g_{c} F_{c s}}{1-F_{c s}}
\end{aligned}
$$

where,

$\mathbf{r}_{\mathrm{d}}^{\mathbf{f}}, \mathbf{r}_{\mathrm{ps}}^{\mathbf{f}}, \mathbf{r}_{\mathrm{cs}}^{\mathbf{f}}$ are the rates of return on new debt (pre-tax), preferred stock, and common stock, respectively,

$\mathrm{F}_{\mathrm{d}}, \mathrm{F}_{\mathrm{ps}}, \mathrm{F}_{\mathrm{cs}}$ are the flotation costs of debt (after-tax), preferred stock, and common stock, respectively, $\mathrm{PV}_{\mathrm{d}}, \mathrm{PMT}_{\mathrm{d}}, \mathrm{FV}_{\mathrm{d}}$ are the present value, coupon payments, and face value of debt maturing at time $t$, and $\mathrm{g}_{\mathrm{c}}$ is the constant rate at which firm's dividends (and profits) can grow perpetually.

The new costs of capital obtained above are used in equations (2) and (1) to estimate the project's weighted average cost of capital, and consequently the net present value.

We note that Brigham and Houston (2007) use a modified version of the Gordon's dividend discount model to estimate rate of return on new common stock as $\mathbf{r}_{\mathrm{cs}}^{\mathrm{f}}=\frac{\mathbf{D}_{1}}{\mathbf{P}_{\mathbf{0}}\left(\mathbf{1}-\mathbf{F}_{\mathrm{cs}}\right)}+\mathbf{g}$ for a firm whose common stock trades at a price $\mathrm{P}_{0}$, is expected to pay a dividend $\mathrm{D}_{1}$, and is expected to grow at a constant rate $\mathrm{g}_{\mathrm{c}}$. We rewrite in this form for easier exposition. 


\section{INCORPORATING FLOTATION COSTS USING AN ALTERNATE APPROACH}

The traditional approach is biased towards assigning a higher value to the weighted average cost of capital, and a lower value to the initial investment. This leads to significant errors in measuring net present value. The measurement errors arise primarily since flotation costs are a one-time cash-flow event, incurred only when firms raise capital. Consequently, they should not materially impact the cost of capital of the firm or of the project. We describe here an alternate approach that mitigates these shortcomings, and which can be generalized to any capital budgeting process. This method is more precise, and can be easily applied to any general capital budgeting decision.

Assuming, the firm retains its current capital structure for the project, we estimate a weighted average flotation cost $\left(\mathrm{F}_{\mathrm{WAFC}}\right)$ for the project as:

$\mathbf{F}_{\mathrm{WAFC}}=\mathbf{w}_{\mathrm{d}} \mathbf{F}_{\mathrm{d}}+\mathbf{w}_{\mathrm{ps}} \mathbf{F}_{\mathrm{ps}}+\mathbf{w}_{\mathrm{cs}} \mathbf{F}_{\mathrm{cs}}$

We then calculate a new initial investment that reflects the weighted average flotation costs of all capital components as:

$$
\mathbf{C}_{0}^{\mathrm{f}}=\left[\frac{\mathbf{C}_{\mathbf{0}}}{1-\mathbf{F}_{\mathrm{WAFC}}}\right]\left(1-\mathbf{F}_{\mathrm{WAFC}} \mathrm{T}\right)
$$

Net present value of the project can then be more precisely calculated using the firm's weighted average cost of capital, with this new initial investment.

We note that we assumed the company retains its current capital structure for the project only for ease of exposition. Deviation in target project capital structure from that of the firm's, could be accommodated by modifying the capital weights in equations (2) and (4).

\section{CAPITAL BUDGETING IMPLICATIONS: COMPREHENSIVE EXAMPLE}

Consider a firm that has a capital structure comprised of 30 percent debt, 10 percent preferred stock, and 60 percent common stock. Management uses the yield-to-maturity on the company's 30-year bonds to estimate its cost of debt: the coupon rate on these bonds is 10 percent, and they currently trade at par. The company's preferred stock has a dividend yield of 7.6 percent and trades at a par value of \$50. The firm uses the Gordon's dividend discount model to estimate its cost of common equity: the common stock trades at $\$ 50$, the previous year's annual dividend was $\$ 4.19$, and earnings and dividends are estimated to grow at a constant rate of 5 percent. The marginal federalplus-state tax bracket of the firm is 40 percent. The firm estimates its cost of raising debt, preferred stock, and common stock as 2 percent, 5 percent, and 15 percent, respectively.

Management is evaluating two independent projects for investment. Though, the project funding retains the same relative capital components as the firm, it is financed entirely with new (external) investment capital. The first project requires an investment today of $\$ 10$ million, and is expected to generate future year-end cash-flows of $\$ 1.26$ million in each of the following 25 years. The second project entails a similar initial investment, but generates an annual cash-flow $\$ 1.8$ million for 10 years.

\section{Project Analysis: Ignoring Flotation Costs}

In Table 1, we present the NPV valuation of these capital budgeting decisions, without considering flotation costs: 
Table 1: NPV Calculation without Flotation Costs

\begin{tabular}{|c|c|c|}
\hline Capital Component & Calculation & Result \\
\hline Cost of Debt & $1000=\sum_{j=1}^{30} \frac{100 *(1-40 \%)}{\left(1+r_{d}\right)^{j}}+\frac{1000}{\left(1+r_{d}\right)^{30}}$ & $6.0 \%$ \\
\hline Cost of Preferred Stock & $\mathbf{r}_{\mathrm{ps}}=\frac{\mathbf{\$ 3 . 8}}{\mathbf{\$ 5 0}}$ & $7.6 \%$ \\
\hline Cost of Common Stock & $r_{\mathrm{cs}}=\frac{\$ 4.19 * 1.05}{\$ 50}+5 \%$ & $13.8 \%$ \\
\hline WACC & $\mathrm{WACC}=0.3 * 6 \%+0.1 * 7.6 \%+0.6 * 13.8 \%$ & $10.84 \%$ \\
\hline NPV of First Project & $\mathrm{NPV}=-10000+\sum_{i=1}^{25} \frac{1260}{(1.1084)^{i}}$ & $+\$ 736,607$ \\
\hline NPV of Second Project & $\mathrm{NPV}=-10000+\sum_{i=1}^{10} \frac{1800}{(1.1084)^{i}}$ & $+\$ 672,115$ \\
\hline
\end{tabular}

Without flotation costs, the manager would clearly choose to invest in both projects since project NPVs are greater than zero.

\section{Project Analysis: Using the Traditional Approach} flotation costs:

In Table 2, we rework the NPV valuation using the prevalent approach in most textbooks for factoring

Table 2: NPV Calculation using the Traditional Consideration of Flotation Costs

\begin{tabular}{|c|c|c|}
\hline Capital Component & Calculation & Result \\
\hline Cost of Debt & $1000 *(1-2 \%)=\sum_{j=1}^{30} \frac{100 *(1-40 \%)}{\left(1+r_{d}^{f}\right)^{j}}+\frac{1000}{\left(1+r_{d}^{f}\right)^{30}}$ & $6.15 \%$ \\
\hline Cost of Preferred Stock & $r_{p s}^{f}=\frac{7.6 \%}{1-5 \%}$ & $8.0 \%$ \\
\hline Cost of Common Stock & $r_{\mathrm{cs}}^{\mathrm{f}}=\frac{13.8 \%-5 \% * 15 \%}{1-15 \%}$ & $15.35 \%$ \\
\hline WACC & $\mathrm{WACC}=0.3 * 6.15 \%+0.1 * 8.0 \%+0.6 * 15.35 \%$ & $11.86 \%$ \\
\hline NPV of First Project & $\mathrm{NPV}=-10000+\sum_{i=1}^{25} \frac{1260}{(1.1186)^{i}}$ & $-\$ 20,840$ \\
\hline NPV of Second Project & $\mathrm{NPV}=-10000+\sum_{\mathrm{i}=1}^{10} \frac{1800}{(1.1186)^{\mathrm{i}}}$ & $+\$ 228,952$ \\
\hline
\end{tabular}

Using the traditional approach to factor in flotation costs, the manager's decision would be to reject the first project (negative NPV), and accept the second project (positive NPV).

\section{Project Analysis: Using the Alternate Approach}

Table 3 provides a detailed working of NPV valuations using the alternate approach of considering flotation costs: 
Table 3: NPV Calculation using the Alternate Approach for Consideration of Flotation Costs

\begin{tabular}{|c|c|c|}
\hline Capital Component & Calculation & Result \\
\hline Cost of Debt & $1000=\sum_{j=1}^{30} \frac{100 *(1-40 \%)}{\left(1+r_{d}\right)^{j}}+\frac{1000}{\left(1+r_{d}\right)^{30}}$ & $6.0 \%$ \\
\hline Cost of Preferred Stock & $\mathbf{r}_{\mathrm{ps}}=\frac{\$ 3.8}{\$ 50}$ & $7.6 \%$ \\
\hline Cost of Common Stock & $r_{\mathrm{cs}}=\frac{\$ 4.19 * 1.05}{\$ 50}+5 \%$ & $13.8 \%$ \\
\hline WACC & $\mathrm{WACC}=0.3 * 6 \%+0.1 * 7.6 \%+0.6 * 13.8 \%$ & $10.84 \%$ \\
\hline Weighted Average Flotation Cost & $\mathrm{F}_{\mathrm{WAFC}}=0.3 * 2 \%+0.1 * 5 \%+0.6 * 15 \%$ & $10.1 \%$ \\
\hline Adjusted Initial Investment & $C_{0}^{f}=\left[\frac{-10000}{1-10.1 \%}\right](1-10.1 \% * 40 \%)$ & $-\$ 10,674,000$ \\
\hline NPV of First Project & $\mathrm{NPV}=-10674+\sum_{\mathrm{i}=1}^{25} \frac{1260}{(1.1084)^{\mathrm{i}}}$ & $+\$ 62,607$ \\
\hline NPV of Second Project & $\mathrm{NPV}=-10674+\sum_{i=1}^{10} \frac{1800}{(1.1084)^{i}}$ & $-\$ 1,885$ \\
\hline
\end{tabular}

The alternate approach to factoring in project costs reverses the manager's decision. He would now accept only the first project since it has a positive NPV; the second project now has negative NPV. Clearly, under some circumstances, the two approaches may provide contradictory results.

\section{CONCLUSION}

Through the detailed calculations above, we illustrate that a project analysis based on the approach popular in most textbooks would force the manager to reject the viable first project, while accepting the unprofitable second project. This is a measurement problem inherent in the prevalent approach, and arises because the traditional method calculates a higher cost of capital, while keeping the initial cash-flow unchanged. As demonstrated above, the bias is magnified for projects with longer paybacks, and large long-run cash-flows.

We demonstrate an alternate approach that corrects for this problem by assigning a higher initial investment due to flotation costs, while keeping the cost of capital unchanged. Though we demonstrate the appropriateness of the alternate method using NPV as the decision criteria, the issue highlighted would apply to other capital budgeting decision criteria. Surprisingly, this approach is not found in the commonly-used textbooks for finance courses.

\section{AUTHOR INFORMATION}

Neeraj J. Gupta, Ph.D., CFA, assistant professor of finance at the Martha and Spencer Love School of Business of Elon University, has a doctorate in finance from the University of Connecticut, and is a CFA charterholder. His research interests are in investments, corporate finance, and international finance.

Wonhi Synn, Ph.D. is a professor of finance at the Martha and Spencer Love School of Business of Elon University. Dr. Synn has previously published in the areas of online stock trading, bankruptcy, government sponsored enterprises, business curriculum and pedagogy. Dr. Synn received his Ph.D. from the State University of New York at Buffalo. 


\section{REFERENCES}

1. Graham, J. R., and Harvey, C. R. (2001), The Theory and Practice of Corporate Finance: Evidence from the Field, Journal of Financial Economics, 187-243.

2. Brealey, R. A., and Myers, S. C. (2000), Principles of Corporate Finance, New York, New York: Irwin/McGraw-Hill.

3. Brealey, R. A., Myers, S. C., and Marcus, A. J. (2007), Fundamentals of Corporate Finance, New York, New York: Irwin/McGraw-Hill.

4. Brigham, E. F., and Houston, J. F. (2007), Fundamentals of Financial Management, Mason, Ohio: SouthWestern.

5. Brigham, E. F., and Ehrhardt, M. C. (2005), Financial Management: Theory and Practice, Mason, Ohio: South-Western.

6. Ross, S. A., Westerfield, R. W., and Jaffe, J. F. (2002), Corporate Finance, New York, New York: Irwin/McGraw-Hill.

7. Ross, S. A., Westerfield, R. W., and Jordan, B. D. (2002), Fundamentals of Corporate Finance, New York, New York: Irwin/McGraw-Hill. 